\title{
Selected minerals concentration and microbiological safety in non-carcass bovine components of "PANELADA" dish
}

\author{
Ana Kledna Leite ROQUE ${ }^{1}$, Mikael Kélvin de Albuquerque MENDES ${ }^{1}$, Rodolfo CARAPELLI ${ }^{2}$, \\ Cícero Alves LOPES JÚNIOR ${ }^{1 \star ~(D), ~ E d i v a n ~ C a r v a l h o ~ V I E I R A ~}{ }^{1 \star}$
}

\begin{abstract}
"Panelada" is a typical dish from Brazil, made up of some bovine non-carcass components (intestine, rumen and ox feet), whose nutritional value and microbiological quality are not reported. The total contents of selected minerals were determined using flame atomic absorption spectrometry (FAAS) and electrothermal (ETAAS) for samples of raw, seasoned and Panelada dish. The content of metal nutrients found in raw sample was higher than for various types of conventional cuts and meats. The added seasoning increased of the content of metal nutrients comparing to from raw sample, except for $\mathrm{Zn}$. Instead, the cooking process interferes negatively in the minerals content, in contrast to $\mathrm{Mg}$ concentration. The Panelada dish presented high nutritional value being found 3.3, 79, 334 and $75 \mathrm{mg} \mathrm{kg}^{-1}$ for $\mathrm{Cu}, \mathrm{Fe}, \mathrm{Mg}$ and $\mathrm{Zn}$, respectively. The microbiological analyses revealed absence of Escherichia coli, Salmonella spp. and Listeria monocytogenes from Panelada dish.
\end{abstract}

Keywords: Panelada dish; bovine non-carcass components; mineral nutrient; microbiological quality; food safety.

Practical Application: Evaluation on nutrient content and microbiological quality of Panelada dish.

\section{Introduction}

The production of animal protein plays an important role in the efficiency of food production systems and it has contributed to the development and elimination of poverty in human society (Sun \& Guan, 2018). Most studies on the performance of bovine cuts mainly address the production characteristics, such as weight gain and carcass quality (Niedermayer et al., 2017), disregarding the parts that do not belong to the carcass and that correspond to approximately $54-56 \%$ of their body mass (Marti et al., 2012). However, some industries in developing countries have shown an interest in exploring the qualitative and quantitative characteristics of non-carcass components such as liver, heart, kidneys, brain, spleen, lungs and intestines due to the viability of using carcass components in the economic scenario (Mushi et al., 2009).

In Brazil, these non-carcass components are used for consumption in the form of a dish popularly known as "Panelada". This typical dish of the Brazilian Northeastern cuisine is prepared with the intestine, rumen and pieces of ox paws. Panelada is well accepted by consumers. This dish makes up the menu from popular establishments to the high economic level (Gomes, 2019). The feeding based on the consumption of non-carcass bovine components is also carried out in other countries. For example, tripes are consumed in the form of traditional dishes such as Blóomör, Dinuguan, Korouch, Callos, Cold appetizer, Haggis and Pieds et paquets present in the cuisine of Iceland, Philippines, Lebanon, Spain, Chine, Scotland and France (Toldrá et al., 2012).
The searches performed in the different databases confirmed the absence of nutritional information for Panelada, being obtained only a small number of publications reporting the characteristics of a similar dish, "Buchada" which is prepared with sheep and goat viscera (De Queiroz et al., 2013, 2017; Madruga \& Bressan, 2011).

For determination of metals nutrients, in biological matrices, techniques with adequate sensitivity are required. In fact, ICP-MS allows the detection of elements at trace level and ultratrace in several matrices, e.g. food, as well as isotope experiments. ICP OES is also a multielement technique with wide linear range (He et al., 2017; Santos et al., 2017; Wilschefski \& Baxter, 2019). However, these techniques cost much more than Flame atomic absorption spectrometry (FAAS) and Electrothermal atomic absorption spectrometry (ETAAS). FAAS is considered a robust, low-cost and high analytical frequency technique, enabling reliable measurements at low concentration levels (Kilinç et al., 2012; Özzeybek et al., 2017). While the ETAAS has as main advantages the complete analyte atomization, elimination of organic components by thermal treatment prior to vaporization and atomization of the metals and use of small sample volumes only a few microliters of sample (Fernández et al., 2019; Wilschefski \& Baxter, 2019).

Food safety is an important factor related to public health. Food intake is the main route for pathogen entry into the human body which causes disease, in some cases death. The developing countries population has been the biggest victim due to the 
lack of sanitary conditions. This problem has raised the cost with public health for several billion dollars (Aiyegoro, 2014). Although obtained under ideal hygienic conditions the viscera present high microbial load resulting from the natural microbiota of the animal organism (Madruga et al., 2003). Regarding the absence of information, the microbiological quality of Panelada dish was investigated.

Considering the lack of information on the metal content nutrients, the objective of this work was also to investigate the $\mathrm{Fe}, \mathrm{Mg}$ and $\mathrm{Zn}$ contents by FAAS and the determination of the $\mathrm{Cu}$ content using ETAAS in samples of raw, seasoned and Panelada dish (seasoned and cooked).

\section{Materials and methods}

\subsection{Samples}

Panelada samples consisting of tripe, gut (large and small intestines) and pieces of bovine feets were purchased from a market at Teresina, BR. The non-carcass components were used from Nellore adult males' cattle. For sample formulation of the following components: tripe, gut and pieces of bovine feet were used and manually divided into pieces of $c a .3 \mathrm{~cm}$. The non-carcass components were mixing manually and partitioned into three equal portions. For analysis, the samples were considered in three stages: raw, seasoned (SP) and seasoned and cooked (SCP). The method applied in the preparation of SP and SCP samples was derived from Panelada dish preparation by local culture. In the preparation of SP samples, $c a .250 \mathrm{~g}$ of the mixture of the non-carcass components was incubated for $10 \mathrm{~min}$ with juice from 2 lemons. After incubation, the seasonings were added in the following quantities: $0.75 \mathrm{~g}$ garlic, $0.5 \mathrm{~g}$ salt, $2.5 \mathrm{~mL}$ vinegar, $0.5 \mathrm{~g}$ powdered pepper, $0.25 \mathrm{~g}$ food colouring, $3.0 \mathrm{~g}$ green onion and $3.0 \mathrm{~g}$ parsley, $1.25 \mathrm{~g}$ chopped pepper, $25 \mathrm{~g}$ chili chopped, $42.5 \mathrm{~g}$ chopped onion, $50 \mathrm{~g}$ chopped tomato, $0.5 \mathrm{~g}$ bay leaf and 1 lemon juice. Finally, the mixture was manually mixed for $2 \mathrm{~min}$. The preparation of the SCP sample was done with the addition of the same seasonings used for the SP sample, except for $5 \mathrm{~mL}$ of soybean oil and $250 \mathrm{~mL}$ of water. The cooking samples were carried out in a domestic pressure cooker for $40 \mathrm{~min}$ at $c a$. $120^{\circ} \mathrm{C}$ similar conditions applied traditionally and restaurants. Then, Panelada dish was obtained in the form for consumption. Each preparation procedure was applied three times in order to obtain independent sample replicates.

The raw, SP and SCP samples were manually divided into smaller pieces, homogenized in domestic multiprocessor, stored in polyethylene bottles and store at $4{ }^{\circ} \mathrm{C}$. The samples were lyophilized for $48 \mathrm{~h}$. At the end, the samples were pulverized in a cryogenic mill using liquid nitrogen and the following program: $16 \mathrm{~Hz}$ frequency, total time of $10 \mathrm{~min}$, intercalated between freezing at $2 \mathrm{~min}$ and milling at $1 \mathrm{~min}$.

\subsection{Method for selected minerals quantification}

For mineral analysis, ca. $250 \mathrm{mg}$ of each dried and pulverized sample was digested with the mixture of $5 \mathrm{~mL}$ of $\mathrm{HNO}_{3 \mathrm{co}}$ and $2 \mathrm{~mL}$ of $\mathrm{H}_{2} \mathrm{O}_{2} 30 \%$ ( $\left.w: w\right)$ using a teflon closed bottle and subjected to the following microwave program (Multiwave 3000, Anto Parr, Graz, Austria): (1) $100{ }^{\circ} \mathrm{C}$ in $6 \mathrm{~min}$, (2) $180{ }^{\circ} \mathrm{C}$ in
$5 \mathrm{~min}$, (3) $200^{\circ} \mathrm{C}$ in $15 \mathrm{~min}$ e (4) $0{ }^{\circ} \mathrm{C}$ in $20 \mathrm{~min}$, being pressure rate $0.5 \mathrm{bar} \mathrm{s}^{-1}$, infrared at $210^{\circ} \mathrm{C}$ and power of $1000 \mathrm{~W}$. At the end, the sample solution was cooled, evaporated and diluted to $25 \mathrm{~mL}$ with deionized water $\left(\geq 18.2 \mathrm{M} \Omega . \mathrm{cm}, \mathrm{Milli}^{\circledR}-\mathrm{Q}\right.$ Direct 8/16, Molsheim, France). Triplicate of each sample was made, and blank was also prepared for each analysis. The total determination of $\mathrm{Fe}, \mathrm{Mg}$ and $\mathrm{Zn}$ was performed using FAAS 240FS (Varian, Mulgrave, Australia) operating under optimized instrumental conditions. The total copper determination was done using ETAAS. The optimization of the pyrolysis and atomization temperature was carried out using a solution of $30 \mu \mathrm{g} \mathrm{L}^{-1} \mathrm{Cu}$ added to the solution of the raw sample and $5 \mu \mathrm{L}$ of $1000 \mathrm{mg} \mathrm{L}^{-1} \mathrm{Mg}\left(\mathrm{NO}_{3}\right)_{2}$ as chemical modifier.

Bovine Liver Certified Material (1577b) was analyzed under the same conditions described above to verify the accuracy of the proposed method.

\subsection{Microbiological analysis}

Microbiological analysis was performed for raw and SCP samples. The assays for determination of total and thermotolerant coliforms, E. coli, Clostridium sulfite reductant, Staphylococcus aureus and test for detection of Salmonella spp. and Listeria monocytogenes were performed according to the method described by American Public Health Association (2001).

\subsection{Statistical analysis and figures of merit}

All the experiments were carried out in triplicates. All the data were expressed as mean \pm standard deviation. The $t$ test, ANOVA, Tukey's test $(\mathrm{p}<0.05)$ and fit linear were used for statistical analysis of the data. The limit of detection (LOD) and limit of quantification (LOQ) of the methods were based on the calibration curve using the following equations (Equation 1).

$L O D=\frac{3.3 \sigma}{S} \quad L O Q=\frac{10 \sigma}{S}$

The value of $\mathrm{S}$ corresponds to the slope of the calibration curve. The value of $\sigma$ is the standard deviation $(n=10)$ of the sample blank.

\section{Results and discussion}

FAAS showed insufficient detectability for determination of copper in Panelada samples. Therefore, the analyzes were performed using ETAAS that detects low level of copper in samples. Therefore, the optimization of pyrolysis and atomization temperatures in ETAAS was performed.

Figure 1 shows the pyrolysis and atomization curves using a raw digested sample solution enriched with $30 \mu \mathrm{g} \mathrm{L}^{-1} \mathrm{Cu}$ and $5 \mu \mathrm{L}$ of chemical modifier $1000 \mathrm{mg} \mathrm{L}^{-1} \mathrm{Mg}\left(\mathrm{NO}_{3}\right)_{2}$ in $1 \%(v / v) \mathrm{HNO}_{3}$. The highest pyrolysis temperature obtained with the highest signal-to-noise ratio of $\mathrm{Cu}$ was $1000^{\circ} \mathrm{C}$, while $1900^{\circ} \mathrm{C}$ was the atomization temperature with the most intense analyte signal.

The optimized instrumental operating conditions on FAAS and ETAAS as well as the parameters estimated and the results obtained are in the Supplementary material - Table S1 and S2. 
Previously, the reliability of the proposed method by analysis of the certified equivalent food material, Bovine Liver (NIST 1577b). The concentration found for $\mathrm{Cu}, \mathrm{Fe}, \mathrm{Mg}$ and $\mathrm{Zn}$ are shown in Table 1 . The values found are consistent with the certified concentration values according to the paired $t$ test, at 95\% confidence level. These results confirm the accuracy of the proposed analytical method for the determination of metal nutrient elements in the different samples.

Our study performed the analysis of the metals nutrients copper, iron, magnesium and zinc in Panelada samples at different stages and the results are in Table 2. Relevant content of the metals nutrient in the Panelada was found. Comparing the obtained values, there are significant differences, except between the concentration of $\mathrm{Cu}$ between the raw and seasoned samples according to the Tukey test $(\mathrm{p}<0.05)$. The total content of iron

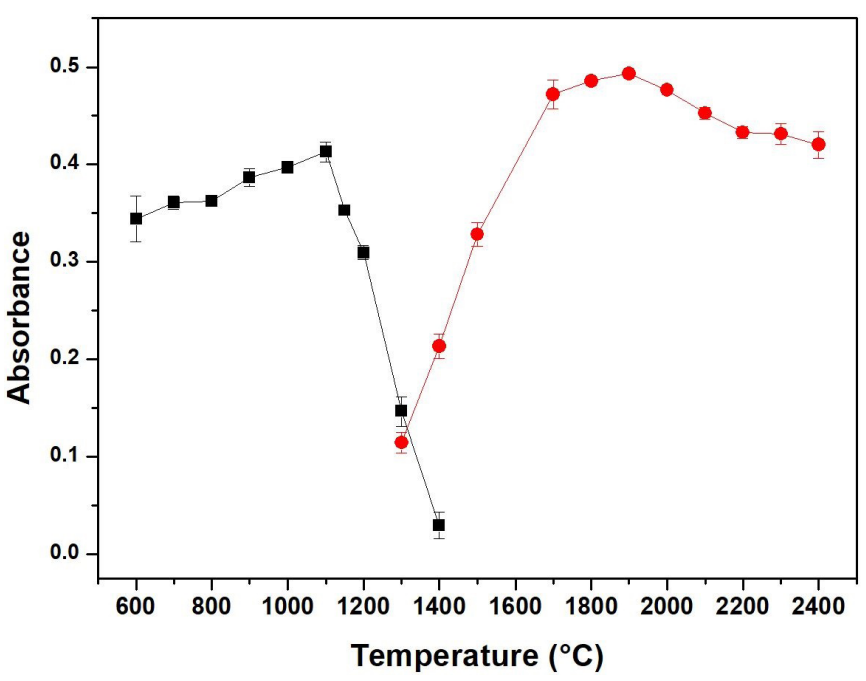

Figure 1. Pyrolysis and atomization curves, obtained from measurements (absorbance $\pm \mathrm{sd}, \mathrm{n}=4$ ) of the sample solution raw after digestion process enriched $30 \mu \mathrm{g} \mathrm{L}-1 \mathrm{Cu}$ and $5 \mu \mathrm{L}$ of chemical modifier $\mathrm{Mg}\left(\mathrm{NO}_{3}\right)_{2}$ to $1000 \mathrm{mg} \mathrm{L}^{-1}$.

Table 1. Determination of nutrient metal elements (mean values $\pm \mathrm{sd}$, $\mathrm{n}=3$ ) in the certified equivalent food material, bovine liver (NIST 1577b), using FAAS and ETAAS.

\begin{tabular}{clc}
\hline \multirow{2}{*}{ Element } & \multicolumn{2}{c}{ Concentration $\left(\mathrm{mg} \mathrm{kg}^{-1}\right)$} \\
\cline { 2 - 3 } & Certified & Found \\
\hline Copper & $160( \pm 8)$ & $169( \pm 3)$ \\
Iron & $184( \pm 15)$ & $183( \pm 1)$ \\
Magnesium & $601( \pm 28)$ & $608( \pm 8)$ \\
Zinc & $127( \pm 16)$ & $135( \pm 1)$ \\
\hline
\end{tabular}

and magnesium found in SP was higher than $38 \%$ and $10 \%$ when compared to raw, respectively. SP also presented a slightly higher copper content. The observed increase in the nutrients concentration can be attributed to the seasoning process to which the Panelada was subjeced in order to simulate the real condition used for the preparation of the dish subsequently consumed. In contrast, the zinc concentration in the raw Panelada was slightly higher than that of the SP. This fact can be attributed to the previous stage to the addition of seasoning, the washing stage, that the sample was subjected, because in this stage Panelada was treated with water and lemon juice. It is known that lemon has high content of citric acid and ascorbic acid, substances that can decrease the sample $\mathrm{pH}$. According to Cozzolino (2012), the acidic $\mathrm{pH}$ facilitates the zinc compounds solubilization in animal tissues, causing leaching of the nutrient into the medium.

Regarding the effect of the cooking process, it is noted that it was negative as shown in Table 2. The total concentration of copper, iron and zinc found in SCP samples were, approximately, $33 \%, 20 \%$ and $19 \%$ lower than in raw sample. The magnesium content of SCP, according to the $t$ test at $90 \%$ confidence level, it is similar to the value of the raw sample. The conservation processes through refrigeration and freezing as well as thermal processes, such as cooking, can physically alter the meats promoting, thus, changes in the mineral contents (Leygonie et al., 2012; Luo et al., 2018; Menezes et al., 2018). According to Gonçalves et al. (2007) thermal processing promotes copper losses $\mathrm{ca} .50 \%$ in heat-processed, cooled and frozen meats. In our work, a reduction ratio was observed. The total copper concentration in SCP was ca. $41 \%$ lower than that found in SP samples.

Gerber et al. (2009), verified that cooking processes negatively affect concentration of magnesium, with losses ranging about 18 to $34 \%$ for different types of meats. Therefore, cooking processes involving water may adversely affect the mineral content in animal origin food. Gokoglu et al. (2004) upon studying the effects of cooking methods on the composition and mineral content of trouts, found that the magnesium, iron and zinc content decrease significantly in thermal treatments involving not only water, but also in processes such as frying, grilling and microwave cooking. On the contrary, Czerwonka \& Szterk (2015) verified that grilled, roasted and fried bovine meat had higher minerals content ( $\mathrm{Fe}, \mathrm{K}, \mathrm{Mg}, \mathrm{P}$ and $\mathrm{Zn}$ ) than raw meat.

This study revealed that Panelada is an important source for the analyzed metals nutrients, which its use in the diet compared to the other bovine cuts will not cause nutritional damages. In addition, the results showed that the cooking process using water under pressure significantly altered the Panelada mineral profile, and the SCP sample had the lowest copper, iron and zinc

Table 2. Total contents of $\mathrm{Cu}, \mathrm{Fe}, \mathrm{Mg}$ and $\mathrm{Zn}$ (mean values $\pm \mathrm{sd}, \mathrm{n}=3$ ) in different Panelada dish sample.

\begin{tabular}{|c|c|c|c|}
\hline \multirow{2}{*}{ Element } & \multicolumn{3}{|c|}{ Total concentration $\left(\mathrm{mg} \mathrm{kg}^{-1}\right)$} \\
\hline & Raw & $\mathrm{SP}^{\mathrm{a}}$ & $\mathrm{SCP}^{\mathrm{a}}$ \\
\hline Copper & $3.60( \pm 0.21)^{\mathrm{b}, \boldsymbol{.}}$ & $3.95( \pm 0.40) \cdot$ & $2.40( \pm 0.25)^{\bullet}$ \\
\hline Iron & $69.3( \pm 0.8) \cdot$ & $112.5( \pm 5.9)^{\bullet}$ & $55.6( \pm 4.9)^{\star}$ \\
\hline Magnesium & $319.1( \pm 4.7) \cdot$ & $354.9( \pm 2.9) \bullet$ & $328.0( \pm 3.4) \cdot$ \\
\hline Zinc & $81.1( \pm 6.1) \cdot$ & $77.2( \pm 0.5) \cdot$ & $65.7( \pm 4.4) \bullet$ \\
\hline
\end{tabular}

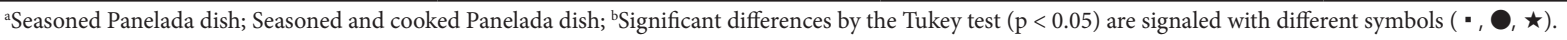


content compared to the others. Except for zinc content, the seasoning process increased the metal nutrients content which was found in the SP sample the highest content of copper, iron and magnesium.

In fact, our study presented new information on the metal nutrient contents of Panelada. Therefore, Table 3 presents a comparison between the total concentration of Fe, $\mathrm{Mg}$ and $\mathrm{Zn}$ found in the raw Panelada sample of our work with that of bovine and other types of cuts reported in the literature.

Comparing the iron content of raw Panelada dish to those reported for different cuts of bovine meat (Table 3 ), it was verified that it is approximately 2.9, 3.4, 3.9, 3.9, 4.3 and 4.9 times higher than those of the fillet, loin, thick flank, beef, rib and chest, respectively (Camargo et al., 2008; Gerber et al., 2009; Lombardi-Boccia et al., 2005; Mohammed et al., 2020). The difference was more significant when compared to the iron content presented by veal cuts (meat of calves), with the content of the nutrient in the Panelada being greater 12, 14 and 6 times than that of chop, breast and veal fillet (Gerber et al., 2009; Lombardi-Boccia et al., 2005). Regarding the comparison of the iron content reported for other types of meat of different animals present in the human diet listed in Table 3, Panelada dish was also superior. For example, the amount of micronutrient found in the typical dish is 3.3, 8.3 and 16.6 times higher than those of pork shank, belly and loin (Gerber et al., 2009; Goran et al., 2016; Menezes et al., 2018).

It be noted that the magnesium in Panelada also presented higher content compared to the other bovine cuts, except for the loin that the magnesium content is 3.2-fold lower (Camargo et al., 2008; Gerber et al., 2009) (Table 3). Compared to meat from other animals, raw Panelada dish showed 34\%, 37\%, 52\% and 98\% higher magnesium content than those reported for chicken chest, pork belly, emu muscle and pork loin (Djinovic-Stojanovic et al.,
2017; Gerber et al., 2009; Goran et al., 2016; Ramos et al., 2009). Another exception, the total magnesium concentration found in pork shank was 2.9-fold higher compared to raw Panelada (Menezes et al., 2018).

As it can be seen in Table 3, the zinc content found in raw Panelada dish was higher in the different types of meat, except for the value found for bovine loin (Camargo et al., 2008), being 45\% lower. For example, the zinc content reported for fish meat is 13- and 21-fold lower than that found in our study for raw Panelada (Bilandžić et al., 2014; Marengo et al., 2018). Considering the copper content, raw sample was higher 9, 7 and 4 times than that of bovine fillet, pork loin and chicken chest, respectively, reported by Lombardi-Boccia et al. (2005). Bilandžić et al. (2012) reported the copper concentration in animal food from Croatia. Comparing with those found in this study, it is observed that $42 \%, 47 \%$ and $20 \%$ lower in bovine meat, pork and fish, respectively. Therefore, this brief relationship between the reported values in the literature and those found in our study showed that Panelada is an important source of copper, iron, zinc and magnesium, being a low-cost food and, additionally, contains negligible bovine products maximizing, thus, the production of this food.

Some data reported on the iron and zinc content in different meats after cooking allowed the comparison. It can be noted that the Panelada dish has a higher content of micronutrients compared to other meats (Supplementary material - Figure S1).

The results on evaluation of the microbiological quality of raw and SCP samples are presented in Table 4. As it can be seen, the Panelada dish presented level of Staphylococcus aureus lower than the limit value established by the Brazilian legislation for raw or cooked meat products (Brasil, 2001). These bacteria have moderate heat resistance which their elimination from food is obtained by cooking for $30 \mathrm{~min}$ (Hennekinne, 2018).

Table 3. Total concentration of $\mathrm{Fe}, \mathrm{Mg}$ and $\mathrm{Zn}$ in different types of raw meat.

\begin{tabular}{|c|c|c|c|c|}
\hline \multirow{2}{*}{ Cut/Animal } & \multicolumn{3}{|c|}{ Total concentration $\left(\mathrm{mg} \mathrm{kg}^{-1}\right)$} & \multirow{2}{*}{ Author } \\
\hline & Iron & Magnesium & Zinc & \\
\hline Panelada & $68.5-70.1$ & $314.4-323.8$ & $75.0-87.2$ & Our study \\
\hline Chest/bovine & $12.5-15.9$ & $153.0-207.0$ & $44.6-49.8$ & (Gerber et al., 2009) \\
\hline Loin/bovine & $18.5-22.7$ & $940-1120$ & $137.2-157.2$ & (Camargo et al., 2008) \\
\hline Beef/bovine & $17.9-18.1$ & $164.8-205.2$ & 34.4- 35.6 & (Mohammed et al., 2020) \\
\hline Rib/bovine & $14.1-18.1$ & 161.0-199 & $39.3-53.7$ & (Gerber et al., 2009) \\
\hline Filet/bovine & $22.7-24.7$ & a- & $38.1-40.1$ & (Lombardi-Boccia et al., 2005) \\
\hline Thick flank/bovine & $16.0-20.0$ & - & $40.9-44.9$ & (Lombardi-Boccia et al., 2005) \\
\hline Shank/pork & $20-22$ & $930-936$ & $44-46$ & (Menezes et al., 2018) \\
\hline Loin/Pork & $1.2-7.2$ & $38.9-42.1$ & $0.96-1.1$ & (Goran et al., 2016) \\
\hline Belly/pork & $7.3-9.3$ & $198.8-201.2$ & $25.1-32.7$ & (Gerber et al., 2009) \\
\hline Chest/chicken & - & $173.6-246.4$ & $5.85-8.43$ & (Djinovic-Stojanovic et al., 2017) \\
\hline Muscle/emu & $26.1-37.9$ & $151.0-153.0$ & $12.2-13.4$ & (Ramos et al., 2009) \\
\hline Rib/veal & $3.8-7.6$ & $177.0-223.0$ & $27.0-34.2$ & (Gerber et al., 2009) \\
\hline Breast/veal & $3.7-6.5$ & $187.0-193.0$ & $23.0-26.2$ & (Gerber et al., 2009) \\
\hline Filet/veal & $11.0-13.0$ & - & $47.1-53.1$ & (Lombardi-Boccia et al., 2005) \\
\hline Meat/fish & - & - & $2.45-9.8$ & (Bilandžić et al., 2014) \\
\hline Seabass/ fish & $2.3-2.6$ & - & 3.7-3.9 & (Marengo et al., 2018) \\
\hline
\end{tabular}

${ }^{a}$-Not evaluated in the study. 
Table 4. Evaluation of the microbiological quality of raw and Panelada dish samples

\begin{tabular}{lcrr}
\hline \multicolumn{1}{c}{ Microorganisms } & \multicolumn{2}{c}{ Sample } & SCP $^{\mathrm{a}}$ \\
\cline { 2 - 4 } & Raw & $<2.0 \times 10^{1}$ & $3.0 \times 10^{3}$ \\
\hline Coagulase-positive Staphylococcus aureus & $<2.0 \times 10^{1}$ & Rended limit $^{\mathrm{b}}\left(\mathrm{CFU} \mathrm{g}^{-1}\right)$ \\
Total coliforms & $>6.3 \times 10^{4}$ & $>6.3 \times 10^{4}$ & $<1.0 \times 10^{3}$ \\
Thermotolerant Coliforms & - & $>6.3 \times 10^{4}$ & $<1.0 \times 10^{3}$ \\
Sulphite-reducing Clostridium & $>6.3 \times 10^{4}$ & absence & - \\
Salmonella spp. & absence & absence & - \\
Listeria monocytogenes & absence & - \\
\hline
\end{tabular}

a Seasoned and cooked Panelada; ${ }^{\text {CC }}$ urrent Brazilian Legislation for microbiological parameters in food (Brasil, 2001); ${ }^{\mathrm{c}}$ Values below detection limit.

The level of S. aureus found from raw samples was also lower than the limit value. However, raw and SCP samples showed values higher than the limit of counts for total coliforms and thermotolerant coliforms.

The level of sulfite-reducing Clostridium was used as a parameter of previous fecal pollution in order to complement the tests involving common indicators such as Escherichia coli and intestinal enterococci. In this study, the values found were higher than those described in the ANVISA (Brasil, 2001) and by the Food and Agriculture Organization of the United Nations (2007) $\left(<1.0 \times 10^{2} \mathrm{CFU} \mathrm{g}^{-1}\right)$ in bovine tripes used as natural sausage casings.

The results reveal the absence of $E$. coli from Panelada dish. The high level of $E$. coli was found in raw samples. This fact may be related to the low efficiency of the cleaning procedure adopted and the high bacterial volume present in the natural microbiota from animal organism. It should be noted that food handlers do not always follow the hygiene standards suggested by legislation. This misconduct may raise bacterial levels in food products to exceed the limit value described in the legislation (Pacholewicz et al., 2016). In contrast, the dish Panelada presented absence of Salmonella spp. and L. monocytogenes.

The literature reports the microbiological quality of non-carcass components of other animals. De Queiroz et al. (2013) evaluated the microbiological safety of the "goat buchada" which was formulated with heart, lungs, liver, intestines, blood and kidney. The results found for total coliforms, thermo-tolerant and sulfite-reducing Clostridium were higher than the limit established by ANVISA. The evaluation of the microbiological quality of non-carcass components of buffaloes such as the head, liver, heart and rumen meat also showed higher values for total coliforms and Staphylococcus (Selvan et al., 2007).

\section{Conclusions}

The objectives of this work were successfully attained by presenting new information on the content of metal nutrients and microbiology quality of Panelada dish. The total content of $\mathrm{Cu}, \mathrm{Fe}, \mathrm{Mn}$ and $\mathrm{Zn}$ in the non-carcass components from raw, seasoned as well as seasoned and cooked stages (Panelada dish) were significant. In fact, the addition of seasoning increased of the nutrient metal content. In contrast, the $\mathrm{Zn}$ content was lower due to its liability in acid medium formed with addition of the lemon juice. The cooking process interferes negatively in the minerals content. Panelada dish presented lower levels of nutrients compared to the raw and SC samples, except the value found for $\mathrm{Mg}$. Normally, the cooking treatment reduces the metal nutrients content in food by the leaching process.

The metal nutrients content found in the non-carcass components used to formulate the Panelada dish was higher than of several types of conventional cuts and meats consumed in human diet.

The microbiological analyzes revealed absence for some pathogens on Panelada dish. However, the level of Clostridium and coliforms were higher than the limit described in the legislation. Therefore, the microbiological quality of Panelada dish was moderate indicating that the manufacturing practices adopted during slaughter, processing, storage and commercialization should be rigorous in order to minimize the level of microbiological contamination and, consequently, to improve food safety.

\section{Acknowledgements}

The authors thank the FAPEPI (301269/2015-7), the CNPq (301269/2015-7) and the CAPES for financial support and fellowships.

\section{References}

Aiyegoro, O. A. (2014). Microbial contamination: microbial contamination of processed meat. In: M. Dikeman, C. Devine (Ed.), Encyclopedia of meat sciences (pp. 289-293). San Diego, USA: Elsevier Academic Press. http://dx.doi.org/10.1016/B978-0-12-384731-7.00249-X.

American Public Health Association - APHA. (2001). Compendium of methods for the microbiological examination of foods (4th ed.). Washington: APHA.

Bilandžić, N., Đokić, M., Sedak, M., Varenina, I., Kolanović, B. S., Oraić, D., \& Zrnčić, S. (2012). Determination of copper in food of animal origin and fish in Croatia. Food Control, 27(2), 284-288. http://dx.doi.org/10.1016/j.foodcont.2012.03.020.

Bilandžić, N., Sedak, M., Đokić, M., Varenina, I., Kolanović, B. S., Božić, Đ., Brstilo, M., \& Šimić, B. (2014). Determination of zinc concentrations in foods of animal origin, fish and shellfish from Croatia and assessment of their contribution to dietary intake. Journal of Food Composition and Analysis, 35(2), 61-66. http:// dx.doi.org/10.1016/j.jfca.2014.04.006.

Brasil. Agência Nacional de Vigilância Sanitária - ANVISA. (2001). Resolução $\mathrm{n}^{\circ}$ 12, de 02 de janeiro de 2001. Diário Oficial [da] República Federativa do Brasil.

Camargo, A. M., Rodrigues, V. C., Ramos, K. C. B. T., Oliveira, É. C. D., \& Medeiros, L. F. D. (2008). Composição mineral da carne de 
bovinos de diferentes grupos genéticos com idades distintas. Revista Brasileira de Saúde e Produção Animal, 9(3), 578-584.

Cozzolino, S. M. F. (2012). Biodisponibilidade de nutrientes (4. ed). Barueri: Manole.

Czerwonka, M., \& Szterk, A. (2015). The effect of meat cuts and thermal processing on selected mineral concentration in beef from Holstein-Friesian bulls. Meat Science, 105, 75-80. http://dx.doi. org/10.1016/j.meatsci.2015.03.011. PMid:25828160.

De Queiroz, A. L. M., Brasil, L. M. S., Silva, J., Magnani, M., De Souza, E. L., \& Madruga, M. S. (2013). Microbiological and nutritional quality of "buchada caprina", an edible goat meat by-product. Small Ruminant Research, 115(1-3), 62-66. http://dx.doi.org/10.1016/j. smallrumres.2013.08.006.

De Queiroz, A. L. M., De Araújo, A. R. R., Pacheco, M. T. B., \& Madruga, M. S. (2017). Potential use of goat viscera to obtain protein hydrolysates. Lebensmittel-Wissenschaft + Technologie, 84, 832-837. http://dx.doi.org/10.1016/j.lwt.2017.06.049.

Djinovic-Stojanovic, J. M., Nikolic, D. M., Vranic, D. V., Babic, J. A., Milijasevic, M. P., Pezo, L. L., \& Jankovic, S. D. (2017). Zinc and magnesium in different types of meat and meat products from the Serbian market. Journal of Food Composition and Analysis, 59, 5054. http://dx.doi.org/10.1016/j.jfca.2017.02.009.

Fernández, B., Lobo, L., \& Pereiro, R. (2019). Atomic absorpton spectrometry: fundamentals, instrumentation and capabilities. In: P. Worsfold, A. Townshend (Ed.), Encyclopedia of analytical science (pp. 137-143). USA: Elsevier.

Food and Agriculture Organization of the United Nations - FAO. (2007). Meat processing technology. For small - to medium - scale producers. Bangkok, Thailand: FAO.

Gerber, N., Scheeder, M. R. L., \& Wenk, C. (2009). The influence of cooking and fat trimming on the actual nutrient intake from meat. Meat Science, 81(1), 148-154. http://dx.doi.org/10.1016/j. meatsci.2008.07.012. PMid:22063975.

Gokoglu, N., Yerlikaya, P., \& Cengiz, E. (2004). Effects of cooking methods on the proximate composition and mineral contents of rainbow trout (Oncorhynchus mykiss). Food Chemistry, 84(1), 1922. http://dx.doi.org/10.1016/S0308-8146(03)00161-4.

Gomes, V. N. (2019). Panelada. Retrieved from http://www.virgiliogomes. com/index.php/cronicas/430-panelada/.

Gonçalves, É. C. B. A., Teodoro, A. J., \& Takase, I. (2007). Teores de cobre em extratos de carne in natura e processada. Food Science and Technology (Campinas), 27(2), 298-302. http://dx.doi.org/10.1590/ S0101-20612007000200015.

Goran, G. V., Tudoreanu, L., Rotaru, E., \& Crivineanu, V. (2016). Comparative study of mineral composition of beef steak and pork chops depending on the thermal preparation method. Meat Science, 118, 117-121. http://dx.doi.org/10.1016/j.meatsci.2016.03.031. PMid:27088876.

He, M., Huang, L., Zhao, B., Chen, B., \& Hu, B. (2017). Advanced functional materials in solid phase extraction for ICP-MS determination of trace elements and their species - a review. Analytica Chimica Acta, 973, 1-24. http://dx.doi.org/10.1016/j.aca.2017.03.047. PMid:28502423.

Hennekinne, J. A. (2018). Staphylococcus aureus as a leading cause of foodborne outbreaks worldwide. In: A. Fetsch (Ed.), Staphylococcus aureus (Chap. 7, pp. 129-146). Cambridge, UK: Academic Press. http://dx.doi.org/10.1016/B978-0-12-809671-0.00007-3.

Kilinç, E., Bakirdere, S., Aydin, F., \& Ataman, O. Y. (2012). Sensitive determination of bismuth by flame atomic absorption spectrometry using atom trapping in a slotted quartz tube and revolatilization with organic solvent pulse. Spectrochimica Acta. Part B, Atomic Spectroscopy, 73, 84-88. http://dx.doi.org/10.1016/j.sab.2012.06.004.
Leygonie, C., Britz, T. J., \& Hoffman, L. C. (2012). Impact of freezing and thawing on the quality of meat. Meat Science, 91(2), 93-98. http://dx.doi.org/10.1016/j.meatsci.2012.01.013. PMid:22326063.

Lombardi-Boccia, G., Lanzi, S., \& Aguzzi, A. (2005). Aspects of meat quality: trace elements and B vitamins in raw and cooked meats. Journal of Food Composition and Analysis, 18(1), 39-46. http://dx.doi. org/10.1016/j.jfca.2003.10.007.

Luo, J., Taylor, C., Nebl, T., Ng, K., \& Bennett, L. E. (2018). Effects of macro-nutrient, micro-nutrient composition and cooking conditions on in vitro digestibility of meat and aquatic dietary proteins. Food Chemistry, 254, 292-301. http://dx.doi.org/10.1016/j. foodchem.2018.01.164. PMid:29548456.

Madruga, M. S., \& Bressan, M. C. (2011). Goat meats: description, rational use, certification, processing and technological developments. Small Ruminant Research, 98(1-3), 39-45. http://dx.doi.org/10.1016/j. smallrumres.2011.03.015.

Madruga, M. S., Rezer, J. S., Pedrosa, N. A., \& Melo, H. M. G. (2003). Caracterização química e microbiológica de vísceras caprinas destinadas ao preparo de buchada e picado. Revista Nacional da Carne, 316(27), 37-45.

Marengo, M., Durieux, E. D. H., Ternengo, S., Lejeune, P., Degrange, E., Pasqualini, V., \& Gobert, S. (2018). Comparison of elemental composition in two wild and cultured marine fish and potential risks to human health. Ecotoxicology and Environmental Safety, 158, 204212. http://dx.doi.org/10.1016/j.ecoenv.2018.04.034. PMid:29704791.

Marti, D. L., Johnson, R. J., \& Mathews, K. H. (2012). Where's the (not) Meat? Byproducts from beef and pork production. Journal of Current Issues in Globalization, 5(4), 397-423.

Menezes, E. A., Oliveira, A. F., França, C. J., Souza, G. B., \& Nogueira, A. R. A. (2018). Bioaccessibility of $\mathrm{Ca}, \mathrm{Cu}, \mathrm{Fe}, \mathrm{Mg}, \mathrm{Zn}$, and crude protein in beef, pork and chicken after thermal processing. Food Chemistry, 240, 75-83. http://dx.doi.org/10.1016/j.foodchem.2017.07.090. PMid:28946338.

Mohammed, H. H. H., Jin, G., Ma, M., Khalifa, I., Shukat, R., Elkhedir, A. E., Zeng, Q., \& Noman, A. E. (2020). Comparative characterization of proximate nutritional compositions, microbial quality and safety of camel meat in relation to mutton, beef, and chicken. LebensmittelWissenschaft + Technologie, 118, 108714. http://dx.doi.org/10.1016/j. lwt.2019.108714.

Mushi, D. E., Safari, J., Mtenga, L. A., Kifaro, G. C., \& Eik, L. O. (2009). Growth and distribution of non-carcass components of Small East African and F1 Norwegian crossbred goats under concentrate diets. Livestock Science, 126(1-3), 80-86. http://dx.doi.org/10.1016/j. livsci.2009.06.001.

Niedermayer, E. K., Genther-Schroeder, O. N., Loy, P. A. S., \& Hansen, S. L. (2017). The effects of injectable trace minerals on growth performance and mineral status of Angus beef steers raised in a natural feedlot program. The Professional Animal Scientist, 33(2), 186-193. http://dx.doi.org/10.15232/pas.2016-01570.

Özzeybek, G., Erarpat, S., Chormey, D. S., Fırat, M., Büyükpınar, Ç., Turak, F., \& Bakırdere, S. (2017). Sensitive determination of copper in water samples using dispersive liquid-liquid microextraction-slotted quartz tube-flame atomic absorption spectrometry. Microchemical Journal, 132, 406-410. http://dx.doi.org/10.1016/j.microc.2017.02.031.

Pacholewicz, E., Barus, S. A. S., Swart, A., Havelaar, A. H., Lipman, L. J. A., \& Luning, P. A. (2016). Influence of food handlers' compliance with procedures of poultry carcasses contamination: a case study concerning evisceration in broiler slaughterhouses. Food Control, 68, 367-378. http://dx.doi.org/10.1016/j.foodcont.2016.04.009.

Ramos, A., Cabrera, M. C., Del Puerto, M., \& Saadoun, A. (2009). Minerals, haem and non-haem iron contents of rhea meat. Meat 
Science, 81(1), 116-119. http://dx.doi.org/10.1016/j.meatsci.2008.07.005. PMid:22063970.

Santos, A. F. Jr., Matos, R. A., Andrade, E. M. J., Santos, W. N. L., Magalhães, H. I. F., Costa, F. N., \& Korn, M. G. A. (2017). Multielement determination of macro and micro contents in medicinal plants and phytomedicines from Brazil by ICP OES. Journal of the Brazilian Chemical Society, 28(2), 376-384.

Selvan, P., Mendiratta, S. K., Porteen, K., \& Bhilegaonkar, K. N. (2007). Effect of trisodium phosphate on quality of buffalo offals. American Journal of Food Technology, 2(5), 397-405. http://dx.doi.org/10.3923/ ajft.2007.397.405.

Sun, H. Z., \& Guan, L. L. (2018). Feedomics: Promises for food security with sustainable food animal production. Trends in
Analytical Chemistry, 107, 130-141. http://dx.doi.org/10.1016/j. trac.2018.07.025.

Tabela Brasileira de Composição de Alimentos - TACO (2011). Tabela brasileira de composição de alimentos. Campinas: NEPA - Unicamp.

Toldrá, F., Aristoy, M. C., Mora, L., \& Reig, M. (2012). Innovations in value-addition of edible meat by-products. Meat Science, 92(3), 290-296. http://dx.doi.org/10.1016/j.meatsci.2012.04.004. PMid:22560456.

Wilschefski, S. C., \& Baxter, M. R. (2019). Inductively coupled plasma mass spectrometry: introduction to analytical aspects. The Clinical Biochemist. Reviews / Australian Association of Clinical Biochemists, 40(3), 115-133. PMid:31530963. 


\section{Supplementary Material}

Supplementary material accompanies this paper.

Table S1 - Heating program used to determine the total concentration of $\mathrm{Cu}$ in different samples by ETAAS.

Table S2 - Figures of merit of the proposed analytical method to determine the total $\mathrm{Mg}, \mathrm{Fe}, \mathrm{Zn}$ and $\mathrm{Cu}$ contents in different samples prepared.

Figure S1 - Iron and zinc concentrations (mg kg-1) in different kind of meat after cooking process. SCP - cooked/seasoned Panelada, MB- muscle/bovine; LB - loin/bovine; FP - filet/pork; LP - loin/pork; CC - chest/chicken (Bilandžić et al., 2014; Tabela Brasileira de Composição de Alimentos, 2011).

This material is available as part of the online article from http://www.scielo.br/cta 